\title{
PENGARUH KONSELING KELOMPOK REGULASI DIRI TERHADAP PENINGKATAN REGULASI DIRI PADA PENDERITA PEMBELIAN KOMPULSIF
}

\section{THE EFFECT OF SELF-REGULATION GROUP COUNSELING TO INCREASE SELF REGULATION ON SUBJECT WITH COMPULSIVE BUYING DISORDER}

\author{
Dinda Dwarawati \\ Fakultas Psikologi Universitas Islam Bandung, Bandung \\ Email: dinda.dwarawati@gmail.com
}

\begin{abstract}
The purpose of this research is to understand the effect of self-regulation group counseling for subjects with Compulsive Buying Disorder. The research method was Quasi-experimental, One-group pretestposttest design. Analysis technique used is descriptive statistics. Subjects consist of three, with the criteria are students in college, women, have compulsive buying disorder, and in medium category for selfregulation. The results of this research after 5 group-counseling sessions are: the counselee $1(A P)$ and counselee $3(\mathrm{MM})$ show that they get self-regulation increased scores, but the criteria still exist in the medium category. Counselee 2 (ABF) show that her self-regulation increased scores, with increased category of the category of medium to high category.
\end{abstract}

Key words: self-regulation, compulsive buying, group-counseling.

\begin{abstract}
ABSTRAK
Penelitian ini bertujuan untuk mengetahui pengaruh konseling kelompok self-regulation terhadap peningkatan self-regulation pada penderita gangguan Compulseive Buying. Metode penelitian yang dipakai adalah Quasi experimental, desain One-Group Pretest-Posttest Design. Teknik analisis yang digunakan adalah statistik deskriptif. Subjek penelitian berjumlah 3 (tiga) orang, dengan kriteria: mahasiswa, perempuan, memiliki gangguan pembelian kompulsif, dan diduga memiliki self-regulation sedang. Hasil yang diperoleh setelah melakukan konseling kelompok 5 sesi, yaitu Konseli 1 (AP) dan konseli 3 (MM) mengalami peningkatan peningkatan skor self-regulation sebelum dan sesudah konseling kelompok, namun kriterianya masih ada di kategori sedang. Konseli 2 (ABF) mengalami peningkatan peningkatan skor self-regulation sebelum dan sesudah konseling kelompok, serta mengalami peningkatan kategori dari kategori sedang ke kategori tinggi.
\end{abstract}

Kata Kunci: self-regulation, pembelian kompulsif, konseling kelompok.

Bagi banyak orang konsep adiksi biasanya berkaitan dengan obat-obatan. Tidak mengherankan jika adiksi didefinisikan sebagai penggunaan obat-obatan secara kompulsif dan tidak terkontrol (Diclemente, 2003). Namun, saat ini perilaku adiksi telah berkembang pada tingkah laku tertentu yang memiliki potensi sebagai perilaku adiktif, seperti seks, internet, pornografi, games, dan sebagainya. Oleh karena itu, Orford (Diclemente, 2003) menyatakan bahwa 
adiksi adalah perilaku tertentu yang berulang, kompulsif, self destructive, dan sulit untuk dihentikan atau diubah. Perilaku adiksi tertentu dilakukan sebagai cara untuk menghindari atau menunda masalah-masalah tersebut. Perilaku adiksi merupakan suatu pola perilaku yang memiliki konsekuensi buruk bagi para pecandu dan keluarganya (Peele, dalam Thombs, 2006)

Salah satu jenis adiksi yang yang ada adalah Shopping Addiction atau yang disebut juga pembelian kompulsif (compulsive buying). Sebutan bagi pelakunya adalah shoppacholic. Definisi dari compulsive buying adalah perilaku berbelanja yang kronis dan berulang, yang telah menjadi respon utama dalam situasi atau perasaan negatif (O'Guinn dan Faber, dalam Muller \& Mitchel, 2011). Menurut O'Connor (2003), dengan berbelanja, individu dengan perilaku pembelian kompulsif tidak mengantisipasi reward layaknya seorang penjudi, tetapi sebuah pikiran atau ide ketika berbelanja yaitu seperti telah memiliki suatu objek dan timbulnya kesenangan dan perasaan optimis. Kesenangan tersebut terasa sangat dihayati dalam diri individu sehingga menjadi kekuatan utama ketika berbelanja. Ketika menghadapi perasaan-perasaan negatif dan kesulitan dalam hidup, berbelanja dirasa sebagai cara yang paling ampuh untuk menghilangkannya. Pelaku pembelian kompulsif mengalami kepuasan dan dengan berbelanja seperti telah memberikan makna hidup dan membuatnya lupa akan kesedihan-kesedihannya.

Pembelian kompulsif didasari adanya hasrat menginginkan dari pada membutuhkan item tertentu, sehingga hasrat untuk belanja dapat muncul kapanpun dan di manapun (O'Guinn \& Faber, 1989). Individu dengan perilaku pembelian kompulsif sering berada pada kondisi mendesak sehingga akan mengalami tension (ketegangan) yang mengharuskan mereka untuk segera membeli. Hal tersebut sering terjadi bahkan sebelum individu tersebut berada dalam buying environment. Dengan demikian, secara sederhana dapat dikatakan bahwa pembelian kompulsif itu berkaitan dengan tindakan membeli (act of buying), sementara itu Impulse Buying berkaitan dengan item atau barang yang dibeli. Pada penelitian ini, yang menjadi variabel penelitian adalah individu dengan gangguan pembelian kompulsif.

Peneliti melakukan wawancara terhadap individu dengan gangguan pembelian kompulsif. Individu dalam melakukan kegiatan belanja seringkali memiliki beberapa tujuan, seperti meng- 
ikuti mode atau trend yang selanjutnya akan timbul keyakinan bahwa jika menggunakan barang yang bermerk akan menaikkan harga dirinya dan menghindari menggunakan barang bermerk yang palsu. Tujuan lainnya adalah untuk menghilangkan stres. Mereka merasa dengan melakukan aktivitas berbelanja, maka akan terbebas dari masalah yang saat itu sedang mereka hadapi. Prinsip mereka bahwa dengan berbelanja dan kemudian barang-barangnya akan membuat mereka terkesan mengikuti mode adalah penting.

Tujuan-tujuan tersebut tanpa mempertimbangkan apakah barang yang dibelinya dibutuhkan atau tidak, sehingga barang-barang yang dibelinya sering tidak digunakannya, bahkan ada juga yang subjek lupa menyimpan barang yang telah dibelinya, yang mengakibatkan subjek akan membeli lagi. Banyaknya barang yang dibelinya pun seringkali melebihi dari yang direncanakan. Demikian juga waktu yang dibutuhkan pun cenderung lama, namun tidak jarang juga sangat cepat. Pada akhirnya mereka akan membeli barang yang tidak direncanakan tanpa mempertimbangkan fungsi atau kebutuhan. Subjek nampak tidak memiliki strategi dalam berbelanja, dan cenderung tidak terkontrol.
Dorongan untuk membeli besar dirasakan oleh subjek. Keinginan untuk belanja sering mengganggu kegiatan keseharian mereka. Dorongan belanja bisa sampai muncul dalam mimpi. Ketika mereka berada dalam lingkungan belanja (pertokoan), subjek sering merasa barangbarang yang terpajang di etalase seakanakan meminta mereka untuk membelinya, "mereka seolah-olah melambailambaikan tangan, meminta untuk saya beli. Jantung saya berdebar ketika melihat mereka". Kegiatan berbelanja pun mereka lakukan tanpa mempertimbangkan kondisi keuangan mereka, sehingga sering mereka melakukan berbagai cara untuk dapat berbelanja, seperti membujuk orang tua, menggunakan kartu kredit sampai melebihi batas, sampai berbohong pada orang tua. Bagi mereka, bukan masalah berapa banyak uang yang mereka keluarkan, tetapi kesenangan ketika melakukan aktifitas belanja adalah yang utama. Mereka rela melakukan berbagai cara untuk bisa berbelanja.

Mereka menyadari bahwa perilaku mereka dalam berbelanja tidak seperti teman sebayanya, namun mereka sulit mengendalikan dorongannya untuk berbelanja. Mereka merasa lebih percaya diri jika sudah menggunakan barangbarang yang telah dibelinya. Mereka menyukai reaksi orang-orang disekitarnya 
terhadap dirinya yang menggunakan barang yang dibelinya. Bahkan, subjek merasa senang melihat dirinya sendiri di depan cermin menggunakan barang yang dibelinya, sekalipun tidak pernah digunakannya keluar rumah. Sering teman atau keluarga mengingatkan mereka, namun semakin mereka dilarang, mereka akan semakin sering berbelanja, dan akhirnya memilih berbelanja sendiri tanpa ditemani.

Berdasarkan data wawancara tersebut, peneliti melakukan analisis terhadap penjelasan dari subjek dengan gangguan pembelian kompulsif tersebut. Diperoleh kesimpulan bahwa kegiatan belanja subjek tidak memiliki tujuan, tidak adanya strategi dalam melakukan kegiatan berbelanja yang mengakibatkan kegiatan berbelanja menjadi tidak terkontrol. Subjek sudah melakukan upaya pengendalian, namun selalu gagal. Kemudian meskipun evaluasi terhadap kegiatan belanja sudah dilakukan, subjek selalu akan mengulang kembali kegiatan belanja yang berlebihannya. Dari paparan tersebut, variable yang diperkirakan bermasalah pada subjek adalah pada variabel regulasi diri.

Berdasarkan penelitian pada subjek dengan gangguan pembelian kompulsif mungkin sangat rentan terhadap pola yang negatif untuk berusaha mengubah keadaan atau situasi yang tidak nyaman, yang mempengaruhi perilaku membelinya, karena itu akhirnya mereka sering mengalami kesadaran diri yang justru menyakitkan. Padahal, kesadaran diri merupakan faktor penentu penting untuk menjaga regulasi diri. Untuk mengatur diri, seseorang harus memantau keadaannya, yang meliputi perkembangan melalui lingkungan kemajuan, pelacakan menuju atau jauh dari tujuan, dan mengevaluasi kembali hasil yang diinginkan. Penurunan kesadaran diri (self awareness) terkait dengan rasa malu, yang pada gilirannya menyebabkan kegagalan regulasi diri (Heatherton \& Baumeister, 1991; see Carver, Bab 2). Regulasi diri memfokuskan perhatiannya kepada cara seseorang mengarahkan dan mengontrol dirinya atau perilakunya (Markus \& Wurf, dalam Fiske \& Taylor, 1991).

Regulasi diri memiliki komponen yang penting, yaitu penetapan tujuan, persiapan kognitif untuk berperilaku sesuai dengan tujuan yang hendak dicapai (seperti perencanaan, strategi latihan), monitoring dan evaluasi terhadap semua aktivitas dalam mencapai tujuan yang sudah dicapai (Fiske \& Taylor, 1991).

Beberapa intervensi telah dilakukan untuk mengatasi individu dengan 
gangguan pembelian kompulsif. Salah satunya yang dikemukakan oleh James E. Mitchel yang telah menangani individu dengan pembelian kompulsif dengan pendekatan CBT dengan metode kelompok (Muller \& Mitchel, 2011). Namun, dalam Mithell dan Muller dikemukakan bahwa perlunya memberi intervensi yang melibatkan upaya meningkatkan regulasi diri, karena regulasi diri yang rendah sangat memiliki kontribusi terhadap munculnya gangguan pembelian kompulsif. Dalam intervensi untuk meningkatkan regulasi diri harus juga diupayakan untuk mengajarkan kontrol kepada subjek dapat mengarahkan dirinya agar berbelanja secara lebih sehat dan bertujuan. Dalam intervensi juga perlu pada awalnya subjek dberikan insight akan self-awareness yang ada pada dirinya, sebagai upaya untuk mengenali masalahmasalah dalam dirinya.

Seperti yang telah dikemukakan, bahwa gangguan pembelian kompulsif merupakan gangguan pada pengendalian impuls, sehingga diperlukan intervensi yang memberikan informasi dan pelatihan mengenai dampak negatif dari perilakunya serta mempelajari perilaku baru yang lebih efektif untuk mengganti perilakunya yang lama. Individu dengan gangguan ini, bisa diberikan intervensi dalam bentuk konseling kelompok
(Seligman \& Reichenberg, 2007). Melalui konseling kelompok individu akan saling menceritakan pengalaman yang serupa berkaitan dengan gangguannya. Dalam konseling kelompok juga akan saling bertukar informasi mengenai keberhasilan dan kegagalan dalam mengatasi gangguannya, serta saling memberikan feedback dan dukungan satu sama lain. Konseling kelompok juga akan meningkatkan minat sosialnya serta meningkatkan kemampuannya dalam bersosialisasi. Selain itu juga, memfasilitasi individu untuk berlatih dan menguji defence, membandingkan diri, meningkatkan selfunderstanding dan self-acceptance. Proses tersebut akan mengantarkan subjek untuk meningkatkan regulasi dirinya, sehingga perilaku berbelanja mereka menjadi lebih terarah. Konseling kelompok yang dilakukan bukan bertujuan menghilangkan perilaku belanja subjek, akan tetapi untuk dapat mengarahkan perilaku belanjanya sehingga lebih bertujuan, terkendali dan senantiasa dapat mengevaluasi kegiatan belanjanya, sesuai dengan konsep regulasi diri.

Proses/mekanisme regulasi diri berguna untuk membantu individu dalam monitoring, evaluasi dan mengatur setiap kemajuan dalam mencapai tujuan (Bandura, Carver \& Scheier, dalam Lavallee \& Campbel, 1995). Untuk dapat 
melakukan monitoring dan evaluasi guna mengarahkan dan mengontrol tindakan agar sesuai dengan tujuan yang akan dicapai, pertama-tama orang harus menyadari permasalahannya dengan cara bertanya kepada diri sendiri seterusnya dilanjutkan dengan memberikan instruksi kepada diri sendiri (Woolfolk, 1993). Regulasi diri telah ditandai dengan tiga komponen, yaitu membangun tujuan (establishing a goal), bertindak yang mengarah untuk memperoleh tujuan tersebut (engaging in actions that lead to obtaining this goal), dan memantau kemajuan menuju tujuan (monitoring progress toward the goal) (Baumeister \& Vohs, 2003).

\section{Ahli Social Cognition (Fiske \&} Taylor, 1991) mengemukakan tiga komponen penting regulasi diri. Pertama: Penetapan tujuan. Tujuan pribadi yang telah ditetapkan akan membentuk perilaku-perilaku khusus. Dalam menghadapi situasi sosial, tujuan pribadi sangat erat berkaitan dengan perilaku dan kemampuan seseorang dalam menyesuaikan persepsinya terhadap situasi tertentu dan terhadap faktor-faktor yang muncul. Manusia dapat meninjau beberapa alternatif untuk menginterpretasi kejadian tertentu, mengubah pemahaman karena adanya masukan-masukan yang dipelajari lewat pengalaman, menerapkan sesuatu yang telah diyakininya, nilai-nilai dan tujuan (Showers \& Cantr, dalam Fiske \& Taylor, 1991).

Kedua: Persiapan kognitif agar dapat berperilaku sesuai dengan tujuan yang akan dicapai (perencanaan dan strategi yang terlatih). Persiapan kognitif agar dapat berperilaku sesuai dengan tujuan yang akan dicapai dapat diterangkan dengan menggunakan hierarki tujuan. Carver dan Scheier (Lavalle \& Campbell, 1995) menunjukkan pula bahwa kebanyakan perilaku regulasi diri manusia terjadi pada tahap mempersiapkan dan melaksanakan tindakan konkrit yang disebut program. Bila muncul kejadian yang dirasakan menganggu, barulah manusia meninjau kembali hierarki di atasnya yaitu sistem konsep yang mendasari penetapan tujuan atau prinsip. Tindakan memikirkan satuan program pencapaian tujuan inilah yang disebut mempersiapkan strategi kognitif untuk kemudian diterapkan dalam perilakuperilaku khusus agar tujuan yang telah ditetapkan tercapai. Di antara sejumlah besar kontrol tersebut, Fiske dan Taylor (1991) mengemukakan beberapa yaitu kontrol perilaku, kontrol kognitif, kontrol keputusan, kontrol informasi, kontrol retrospektif dan sekunder.

Ketiga: Monitoring dan evaluasi aktivitas pencapaian tujuan. Dalam 
melakukan monitoring dan evaluasi aktivitas pencapaian tujuan, manusia dibantu oleh proses atau mekanisme regulasi diri (Bandura, Carver \& Scheier, dalam Lavalle \& Campbel, 1995). Proses atau mekanisme regulasi diri itu adalah melakukan peninjauan perilaku dan keseimbangannya, melakukan evaluasi perilaku, serta mengevaluasi reaksi terhadap perilaku yang ditentukan (Bandura \& Stenberg, dalam Woolfolk, 1993).

Ketiga komponen tersebut berorientasi kepada tujuan. Tujuan itu sendiri secara tersirat dan khas merupakan fungsi dari kebutuhan, motif dan nilainilai individual. Komponen Fiske dan Taylor (1991) tersebut didukung oleh pakar yang sependapat bahwa tujuan pribadi adalah sesuatu yang diperjuangkan untuk dicapai serta merupakan komponen penting dan utama yang mengarahkan semua aktivitas (Emmon, dalam Lavelle \& Campbell, 1995)

CB lebih merupakan hasrat atau kebutuhan untuk membeli daripada menginginkan item tertentu ( $\mathrm{O}^{\prime}$ Guinn \& Faber, 1989). Orang-orang yang mengidap CB seringkali mengalami desakan atau ketegangan untuk membeli. Hal ini sering muncul sebelum seseorang berada dalam suatu lingkungan berbelanja. Orang-orang yang mengidap $C B$, cende- rung terikat secara konsisten untuk membeli baik secara rutin/ harian ataupun ketika mereka mengalami emosi negatif. Oleh karena itu, mereka meraih titik di mana kegiatan membeli yang mereka lakukan menciptakan konflik utama dalam kehidupannya. CB dapat dihubungkan dengan kegagalan dalam regulasi diri (Faber \& Vohs, 2004). CB dipandang sebagai kerusakan yang lebih besar dari proses self-regulatory.

Pembelian kompulsif telah didefinisikan sebagai kondisi kronis, pembelian berulang yang, dipelajari terusmenerus, yang kemudian otomatis sebagai respon untuk perasaan negatif (Faber, 2000a; O'Guinn \& Faber, 1989). Membeli menyuguhkan kesenangan jangka pendek tetapi akhirnya menyebabkan kerugian bagi individu dan atau untuk orang lain. Pembelian kompulsif adalah kegagalan terus menerus dalam regulasi diri.

Konseling kelompok (group counseling) merupakan salah satu bentuk konseling dengan memanfaatkan kelompok untuk membantu, memberi umpan balik (feedback) dan pengalaman belajar. Konseling kelompok dalam prosesnya menggunakan prinsip-prinsip dinamika kelompok (group dynamic). Konseling kelompok menurut Gazda (Latipun, 2010), adalah: 
"Group Counseling is a dynamic interpersonal process focusing on conscious thought and behavior and involving the therapy funcstions of permissiveness, orien-tation to reality, catharsis, and mutual trust, caring, understanding, acceptance, and support. The therapy functions are created and nurtured in small group through the sharing of personal concerns with one's peer and the counselor(s)."

Berdasarkan pengertian-pengertian di atas, maka konseling kelompok secara prinsipil adalah sebagai berikut: (1) Konseling kelompok merupakan hubungan antara (beberapa) konselor dengan beberapa klien, (2) Konseling kelompok berfokus pada pemikiran dan tingkah laku yang disadari, (3) Dalam konseling kelompok terdapat faktor-faktor yang merupakan aspek terapi bagi klien, (4) Konseling kelompok bermaksud memberikan dorongan dan pemahaman klien, untuk memecahkan masalah yang dihadapi klien.

Menurut Corey (1995) dan Yalom (1977), konseling kelompok dilaksanakan secara bertahap. Terdapat 6 (enam) tahap dalam konseling kelompok, yaitu prakonseling, tahap permulaan, tahap transisi, tahap kerja-kohensi, tahap akhir, serta tahap tindak lanjut dan evaluasi. Pertama: Prakonseling: Pembentukan kelompok. Tahap ini merupakan tahap persiapan pelaksanaan konseling kelompok. Dalam konseling kelompok yang dipandang penting adalah adanya seleksi anggota. Klien yang dimasukkan sebagai anggota dalam konseling kelompok itu diseleksi terlebih dahulu. Ketentuan yang mendasari penyelenggaraan konseling jenis ini adalah (1) adanya minat bersama (common interest). Dikatakan demikian jika secara potensial anggota itu memiliki kesamaan masalah dan perhatian yang akan dibahas; (2) suka rela atau atas inisiatifnya sendiri, karena hal ini berhubungan dengan hak pribadi klien; (3) adanya kemauan untuk berpartisipasi di dalam proses kelompok; dan (4) mampu untuk berpartisipasi di dalam proses kelompok.

Kedua: Tahap I, yaitu Tahap Permulaan (Orientasi dan Eksplorasi). Pada tahap ini mulai menentukan struktur kelompok, mengeksplorasi harapan anggota, anggota mulai belajar fungsi kelompok, sekaligus mulai menegaskan tujuan kelompok.

Kelompok mulai membangun norma untuk mengontrol aturan-aturan kelompok dan menyadari makna kelompok untuk mencapai tujuan. Peran konselor pada tahap ini membantu menegas- 
kan tujuan untuk kelompok dan makna kelompok untuk mencapai tujuan. Pada tahap ini, menurut Prawitasari (Latipun, 2010), anggota kelompok diajak untuk: bertanggung jawab terhadap kelompok, terlibat dalam proses kelompok, mendorong klien agar berpartisipasi sehingga keuntungan akan diperoleh.

Secara sistematis, pada tahap ini langkah yang dilakukan adalah perkenalan, agenda (tujuan yang ingin dicapai) norma kelompok dan penggalian ide dan perasaan. Jadi tahap permulaan ini anggota memulai menjalin hubungan sesama anggota kelompok. Selain klien mulai memperkenalkan satu sama lain, menyusun saling kepercayaan. Tujuan lanjutnya adalah menjaga hubungan berpusat pada kelompok dan tidak berpusat pada ketua, mendorong komunikasi dalam iklim yang saling menerima dan saling memberi dorongan, membantu memiliki sikap toleran diantara anggota kelompok terhadap perbedaan dan memberikan reinforcement untuk masing-masing anggota (Black dalam Latipun, 2010).

Ketiga: Tahap II atau Tahap Transisi. Pada tahap ini diharapkan masalah yang dihadapi masing-masing klien dirumuskan dan diketahui apa sebab-sebabnya. Anggota kelompok mulai terbuka, tetapi sering terjadi pada fase ini justru terjadi kecemasan, resistensi, konflik dan bahkan ambivalensi tentang keanggotaannya dalam kelompok, atau enggan jika harus membuka diri.

Keempat: Tahap III atau Tahap Kerja-Kohesi dan Produktivitas. Jika masalah yang dihadapi oleh masingmasing anggota kelompok diketahui, langkah berikutnya adalah menyusun rencana-rencana tindakan. Penyusunan tindakan ini disebut pula produktivitas (productivity). Kegiatan konseling kelompok terjadi yang ditandai dengan: membuka diri lebih besar, menghilangkan defensifnya, terjadinya konfrontasi antar anggota kelompok, modeling, belajar perilaku baru, terjadi transferensi. Kohesivitas mulai terbentuk, mulai belajar bertanggung jawab, tidak lagi mengalami kebingungan. Anggota merasa berada dalam kelompok, mendengar yang lain dan terpuaskan dengan kegiatan kelompok.

Kelima: Tahap IV atau Tahap Akhir (Konsolidasi dan Terminasi). Anggota kelompok mulai mencoba melakukan perubahan-perubahan tingkah laku dalam kelompok. Setiap anggota kelompok member umpan balik terhadap yang dilakukan oleh anggota yang lain. Umpan balik ini sangat berguna untuk perbaikan (jika diperlukan) dan dilanjut- 
kan atau diterapkan dalam kehidupan klien jika dipandang telah memadai. Saling mentransfer pengalaman dalam kelompok dalam kehidupan yang lebih luas. Jika ada klien yang memiliki masalah dan belum terselesaikan pada fase sebelumnya, pada fase ini harus diselesaikan. Jika semua peserta merasa puas dengan proses konseling kelompok, maka konseling kelompok dapat diakhiri.

Keenam: Tahap Setelah Konseling atau Tindak Lanjut dan Evaluasi. Setelah berselang beberapa waktu, konseling kelompok perlu dievaluasi. Tindak lanjut dilakukan jika ternyata ada kendalakendala dalam pelaksanaan di lapangan. Mungkin diperlukan upaya perbaikan terhadap rencana-rencana semula, atau perbaikan terhadap cara pelaksanaannya.

\section{METODE PENELITIAN}

\section{Desain Penelitian}

Penelitian ini menggunakan satu kelompok, maka desain eksperimen yang digunakan adalah One Group Design. One Group Design dipilih karena merupakan pengamatan terhadap satu kelompok subjek dengan dua kondisi eksperimen yaitu sebelum dan sesudah treatment, dilakukan untuk mengamati perbedaan individual yaitu perubahan perilaku setiap individu terhadap treatment yang diberikan. Berdasarkan hal tersebut, rancangan penelitian yang digunakan adalah One Group Pretest Posttest Design.

Desain penelitian ini berfungsi menyediakan pengukuran langsung dari perubahan perilaku setiap subjek di bawah dua kondisi observasi yaitu sebelum dan sesudah pemberian treatment. Pengukuran pertama terhadap regulasi diri dilakukan sebelum mengikuti konseling kelompok dan pengukuran regulasi diri kedua dilakukan sesudah perlakuan diberikan yaitu setelah selesai mengikuti konseling kelompok. Gambaran dari rancangan penelitian ini adalah sebagai berikut :

Table 1. One Group Pretest-Posttest Design

\begin{tabular}{cccc}
\hline Group & Pretest & Tratment & Posttest \\
\hline 1 & $\mathrm{Y} 1$ & $\mathrm{X}$ & $\mathrm{Y} 2$ \\
\hline
\end{tabular}

Keterangan :

Y1 = Pengukuran Regulasi diri sebelum memperoleh Konseling Kelompok

$\mathrm{X} \quad=$ Konseling Kelompok Regulasi diri

Y2 = Pengukuran Regulasi diri setelah memperoleh Konseling Kelompok 


\section{Subjek Penelitian}

Penelitian melibatkan 3 (tiga) orang subjek yang memiliki karakteristik (1) Wanita yang sudah memasuki usia perkembangan dewasa awal. Berdasarkan penelitian, $80 \%$ penderita Pembelian kompulsif adalah perempuan.

Mahasiswa, karena pada kriteria ini subjek bertanggung jawab untuk menyelesaikan tugas pendidikannya namun karena gangguan Pembelian kompulsif menjadi terganggu. (3) Memiliki gangguan Pembelian kompulsif, berdasarkan Edward Compulsive Buying dan Questionnaire about Buying Behavior (Black, 2011); (4) Memiliki regulasi diri dengan kategori sedang yang bersedia mengikuti perlakuan yang akan diberikan sampai selesai. Pemilihan kriteria rendah dan atau sedang, karena pada rentang ini ada kemungkinan untuk Regulasi dirinya meningkat.

\section{Teknik Analisis Data}

Teknik analisis data yang digunakan adalah analisis statistik deskriptif. untuk menganalisis data dengan cara mendeskripsikan atau menggambarkan data yang telah terkumpul sebagaimana adanya tanpa bermaksud membuat kesimpulan umum atau generalisasi. Teknik ini dapat digunakan untuk penelitian yang dilakukan pada populasi tanpa diambil sampelnya atau jika peneliti hanya ingin mendeskrispsikan data sampel, dan tidak ingin membuat kesimpulan yang berlaku untuk populasi di mana sampel diambil (Sugiyono, 2008). Secara teknis dapat dapat diketahui bahwa dalam statistik deskriptif tidak ada uji signifikansi, tidak ada taraf kesalahan, karena peneliti tidak bermaksud membuat generalisasi, sehingga tidak ada kesalahan generalisasi (Sugiyono, 2008. Penyajian data dalam statistik deskriptif dapat melalui tabel, grafik, diagram lingkaran, pictogram, perhitugan modus, median, mean (pengukuran tendensi sentral, perhitungan desil, persentil, perhitungan penyebaran penyebaran data melalui perhitungan rata-rata dan standar deviasi, perhitungan prosentase.

Berdasarkan alat ukur regulasi diri, dibuat 3 kategori, yaitu rendah, sedang, tinggi sebagai tolok ukur untuk skor setiap subjek penelitian, dengan cara sebagai berikut. Pertama: Menentukan rentang skor maksimal, yaitu jumlah item dikalikan dengan skor maksimal item. Skor maksimal adalah $4 \times 31=124$. Kedua: Menentukan rentang skor minimal, yaitu jumlah item dikalikan dengan skor minimal item. Skor minimal adalah $1 \times 31=31$. Ketiga: Menentukan lebar rentang skor minimal dan maksimal, kemudian dibagi 3, sehingga diper- 
oleh rentang untuk kategori rendah, (124-31) dibagi $3=31$. sedang dan tinggi. Rentang skor adalah

31

62 rendah

sedang
93 tinggi 124

Keempat: Untuk penskoran setiap Skor maksimal item aspek Penetapan subjek penelitian, maka dilakukan penTujuan adalah $4 \times 7=28$. Skor maksimal jumlahan skor total dari semua item, baik item aspek Strategi Kognitif adalah 4 x 42 sebelum dan sesudah intervensi. Kelima: Membandingkan antara skor total sebelum dan skor total sesudah intervensi, kemudian menghitung selisihnya serta kemudian menghitung persentasenya. Tahapan berikutnya dilanjutkan dengan membuat deskripsi mengenai penurunan derajat stres.

Keenam: untuk menghitung perubahan setiap aspeknya, maka cara menghitungnya adalah (a) Menentukan skor maksimal yaitu jumlah item dikalikan dengan skor maksimal item. $=$ 168. Skor maksimal untuk aspek Monitoring dan Evaluasi adalah $4 \times 7=$ 28. (b) Menentukan skor minimal, yaitu jumlah item dikalikan dengan skor minimal item. Skor minimal item aspek Penetapan Tujuan adalah $1 \times 7=7$. Skor minimal item aspek Strategi Kognitif adalah $1 \times 42=42$. Skor minimal untuk aspek Monitoring dan Evaluasi adalah $1 \times 7=7$. (c) Menentukan rentang skor minimal dan maksimal, kemudian dibagi 3, sehingga diperoleh rentang untuk kategori rendah, sedang dan tinggi.

Rentang skor aspek Penetapan Tujuan adalah ( 28 - 7) dibagi $3=7$

$7_{\text {rendah }}^{14}{ }^{14}{ }^{21}{ }^{\text {sedang }}{ }^{28}$

Rentang skor aspek Strategi Kognitif adalah ( 168 - 42) dibagi $3=42$ 42 84 rendah sedang 126 168 tinggi 
Rentang skor aspek Monitoring dan Evaluasi adalah ( 28 - 7) dibagi $3=7$

$7_{\text {rendah }}^{7}{ }^{14}{ }^{21}{ }^{\text {sedang }}{ }^{28}$

Sementara untuk analisis data Dengan tujuan untuk meningkatkan kualitatif yang dilakukan antara lain : (1) regulasi diri sehingga perilaku $\mathrm{CB}$ akan Membuat pencatatan hasil wawancara berdasarkan proses konseling yang dilakukan dengan subjek. (2) Pengolahan data yang diperoleh dari hasil observasi dan wawancara untuk melihat hal-hal apa saja yang diperkirakan dapat berpengaruh terhadap hasil penelitian yang tidak dapat dilihat secara kuantitatif.

\section{Prosedur Penelitian}

Penyusunan konseling kelompok sesuai dengan tahapan konseling kelompok menurut Corey (1995) dan Yalom (1977). Selain itu dintegrasikan juga dengan konsep sabar dari Islam. turun. Berikut adalah proses pelaksaan konseling yang didalamnya terdapat 6 (enam) tahap dalam konseling kelompok.

(1) Prakonseling: Pembentukan kelompok, (2) Tahap I : Tahap Permulaan (Orientasi dan Eksplorasi), (3) Tahap II : Tahap Transisi, (4) Tahap III: Tahap KerjaKohesi dan Produktivitas, (5) Tahap IV: Tahap Akhir (Konsolidasi dan Terminasi), (6) Setelah Konseling: Tindak Lanjut dan Evaluasi.

\section{HASIL PENELITIAN}

Hasil Perhitungan Statistik

Tabel 2. Tingkat Perubahan Regulasi diri

\begin{tabular}{lcccccc}
\hline Subjek & $\begin{array}{c}\text { Skor } \\
\text { Pre-Test }\end{array}$ & Kategori & $\begin{array}{c}\text { Skor } \\
\text { Post-Test }\end{array}$ & Kategori & \multicolumn{2}{c}{ Peningkatan } \\
Angka & \% \\
\hline 1. AP & 77 & sedang & 83 & sedang & 6 & 7,79 \\
2. ABF & 82 & sedang & 102 & tinggi & 20 & 24,39 \\
3. MM & 78 & sedang & 84 & sedang & 6 & 7,69 \\
\hline
\end{tabular}

Berdasarkan hasil pengukuran terhasil pengukuran awal regulasi diri yaitu hadap peningkatan Regulasi diri yang sebesar 77, berada pada kategori sedang, tergambar pada tabel 2, diperoleh dan pengukuran kedua setelah diberikan gambaran bahwa pada subjek 1 ( AP ), intervensi Konseling Kelompok, meng- 
alami peningkatan skor menjadi 83, yang masih pada kategori sedang. Peningkatan regulasi diri pada Subjek 1 (AP) sebesar 6 poin dengan persentase sebesar $7,79 \%$.

Pada subjek 2 ( $\mathrm{ABF})$, hasil pengukuran awal regulasi diri yaitu sebesar 82, berada pada kategori sedang, dan pengukuran kedua setelah diberikan intervensi Konseling Kelompok, mengalami peningkatan skor menjadi 102, yang masuk pada kategori tinggi.
(ABF) sebesar 20 poin dengan persentase sebesar $24,39 \%$.

Pada subjek 3 (MM), hasil pengukuran awal regulasi diri yaitu sebesar 72, berada pada kategori sedang, dan pengukuran kedua setelah diberikan intervensi Konseling Kelompok, mengalami peningkatan skor menjadi 78, yang masih pada kategori sedang. Peningkatan regulasi diri pada Subjek 3 (MM) sebesar 6 poin dengan persentase sebesar 7,69\%.

Peningkatan Regulasi diri pada Subjek 2

Tabel 3. Perubahan skor aspek-aspek Regulasi diri pada subjek 1 ( AP )

\begin{tabular}{llcccccc}
\hline \multirow{2}{*}{ No. } & \multicolumn{1}{c}{ Aspek } & \multicolumn{2}{c}{ Pre Test } & \multicolumn{2}{c}{ Post Test } & \multicolumn{2}{c}{ Peningkatan } \\
& & Skor & Kriteria & Skor & Kriteria & Angka & $(\%)$ \\
\hline 1. & Penetapan Tujuan & 7 & Rendah & 10 & rendah & 3 & 42,86 \\
2. & $\begin{array}{l}\text { Strategi Kognitif } \\
\text { Monitoring dan }\end{array}$ & 56 & Rendah & 59 & rendah & 3 & 5,36 \\
3. & Evaluasi & 10 & Rendah & 14 & rendah & 4 & 40 \\
\hline
\end{tabular}

Hasil pengukuran akhir untuk sebesar 3 poin dengan persentase sebesar aspek penetapan tujuan mengalami 5,36\% yang masih berada pada kategori peningkatan sebesar 3 poin, dengan rendah. Untuk aspek monitoring dan persentase $42,86 \%$ yang masih berada evaluasi mengalami peningkatan sebesar pada kategori rendah. Untuk aspek 4 poin dengan persentase sebesar $40 \%$ strategi kontrol mengalami peningkatan yang masih berada pada kategori rendah.

Tabel 4. Perubahan skor aspek-aspek Regulasi diri pada subjek 2 ( ABF )

\begin{tabular}{llcccccc}
\hline \multirow{2}{*}{ No. } & \multicolumn{1}{c}{ Aspek } & \multicolumn{2}{c}{ Pre Test } & \multicolumn{2}{c}{ Post Test } & \multicolumn{2}{c}{ Peningkatan } \\
& & Skor & Kriteria & Skor & Kriteria & Angka & $(\%)$ \\
\hline 1. & Penetapan Tujuan & 9 & Rendah & 15 & sedang & 4 & 44,4 \\
2. & $\begin{array}{l}\text { Strategi Kognitif } \\
\text { Monitoring dan }\end{array}$ & 63 & Sedang & 73 & sedang & 12 & 19,05 \\
3. & Evaluasi & 10 & Rendah & 14 & sedang & 4 & 40 \\
\hline
\end{tabular}


Hasil pengukuran akhir untuk aspek penetapan tujuan mengalami peningkatan sebesar 4 poin, dengan persentase $44,4 \%$ yang bergerak dari kategori rendah ke kategori sedang. Untuk aspek strategi kontrol mengalami peningkatan sebesar 12 poin dengan persentase sebesar $19,05 \%$ yang masih berada pada kategori sedang. Aspek monitoring dan evaluasi mengalami peningkatan sebesar 4 poin dengan persentase sebesar $40 \%$ yang bergerak dari kategori rendah ke kategori sedang.

Tabel 5. Perubahan skor aspek-aspek Regulasi diri pada subjek 3 ( MM)

\begin{tabular}{llcccccc}
\hline \multirow{2}{*}{ No. } & \multirow{2}{*}{ Aspek } & \multicolumn{2}{c}{ Pre Test } & \multicolumn{2}{c}{ Post Test } & \multicolumn{2}{c}{ Peningkatan } \\
& & Skor & Kriteria & Skor & Kriteria & Angka & $(\%)$ \\
\hline 1. & Penetapan Tujuan & 12 & Rendah & 12 & rendah & 0 & 0 \\
2. & Strategi Kognitif & 53 & Rendah & 57 & rendah & 4 & 7,54 \\
3. & Monitoring dan Evaluasi & 13 & Rendah & 16 & rendah & 3 & 23,07 \\
\hline
\end{tabular}

Hasil pengukuran akhir untuk aspek penetapan tujuan tidak mengalami peningkatan, sehingga pratest dan pascatest masih berada pada kategori rendah. Untuk aspek strategi kontrol mengalami peningkatan sebesar 4 poin dengan persentase sebesar $7,54 \%$ yang masih berada pada kategori rendah. Untuk aspek monitoring dan evalua.si mengalami peningkatan sebesar 3 poin dengan persentase sebesar $23,07 \%$ yang masih berada pada kategori rendah.

\section{PEMBAHASAN}

Penelitian ini bertujuan untuk mengetahui pengaruh konseling kelompok regulasi diri terhadap peningkatan regulasi diri penderita. Hasil penelitian menunjukkan konseling kelopok regulasi diri terhadap peningkatan regulasi diri penderita. Konseling kelompok dengan tujuan meningkatkan regulasi diri telah dilakukan selama 5 (lima) sesi, dengan jumlah pertemuan yang sama yaitu 5 (lima). Dalam konseling kelompok terdapat 3 (tiga) aspek yang menjadi sasaran dalam diri konseli, yaitu: (1) perubahan dalam tindakan (action) yang teramati, (2) perubahan dalam aspek perasaan, (3) perubahan dalam aspek berpikir konseli. Sasaran perubahan yang ingin dicapai pada diri konseli bisa salah satu dari ketiga aspek tersebut, atau perubahan dalam ketiga aspek tersebut (Paterson, 1986). Konseling kelompok yang telah dilakukan nampaknya telah menyentuh aspek berpikir konseli. Hal 
tersebut sesuai dengan konsep teori dari regulasi diri yang berada pada ranah cognition. Berikut adalah pembahasan secara keseluruhan dari ketiga subjek sebagai konseli yang yang mengikuti rangkaian sesi sebagai sebuah kelompok,

Pada aspek penetapan tujuan, hasil keseluruhan dari aspek ini menunjukkan terjadi peningkatan setelah dilakukan konseling kelompok. Namun peningkatan sebetulnya hanya diperlihatkan oleh AP dan ABF, sementara MM tidak mengalami perubahan. Perubahan signifikan pada aspek ini terlihat pada konsep dari melaksanakan aktivitas berbelanja adalah untuk menghilangkan stres, namun yang menarik adalah hasil yang diperoleh oleh MM, setelah konseling justru MM makin memperkuat prinsipnya, sementara AP dan ABF menurun. Hal tersebut diasumsikan karena masih kuatnya emosi negatif yang MM rasakan kepada saudara dari ibunya. Namun demikian MM menyadari bahwa yang dilakukannya tidaklah efektif, karena reaksi yang diperlihatkan oleh MM membuatnya makin terdorong untuk belanja berlebihan. Bagi MM harga diri di depan saudara menjadi penting.

Kenaikan yang belum signifikan pun sebetulnya ditunjukkan pada prinsip ketiga subjek dalam melakukan kegiatan berbelanja. Tampaknya bagi ketiga subjek mengikuti trend/mode juga tetap menjadi prinsip, meskipun agak menurun pada ABF. Belum kuatnya konsep berbelanja untuk lebih bermanfaat dan terarah, nampaknya belum terlalu signifikan mengalami perubahan. Akibatnya, dengan bahasan pasda aspek ini, tampaknya ketiga subjek dapat mengalami kegagalan dalan regulasi diri yang terus menerus jika prinsip dan konsepnya masih diliputi oleh pengaruh dari luar dirinya. Selama konseling kelompok berlangsung, konselor perlu secara berulang menyampaikan bahwa tujuan dari konseling kelompok adalah meningkatkan pemahaman bahwa kegiatan berbelanja harus lebih terkendali dan terarah, serta harus mampu mengevaluasinya. Hal ini perlu disampaikan berulang, karena hasil dari observasi tampaknya ketiga subjek masih memahami bahwa dengan regulasi diri yang meningkat mereka tidak akan bisa berbelanja. Hal tersebut menurut analisis peneliti membuat konseli mengalami konflik, karena mereka merasa jika berhenti membeli adalah suatu yang tidak mungkin. Mereka baru sangat memahami di sesi ketiga, setelah konselor menyampaikan berulang-ulang.

Asumsi lain yang membuat tidak signifikannya kenaikan pada aspek penetapan tujuan adalah Self-awareness pada diri konseli. Kesadaran bahwa 
setiap melakukan aktivitas itu harus jelas tujuannya, dan memiliki daya guna (manfaat), belum sepenuhnya disadari oleh konseli. Konseli pun masih cenderung sulit menggambarkan tentang dirinya sendiri, bagi mereka lebih mudah jika menceritakan penilaian orang lain padanya, daripada mereka menilai diri sendiri. Sementara ketika menilai diri sendiri, mereka cenderung lebih mudah menilai yang negatif daripada yang positif. Tampak bahwa konsep diri yang terbentuk pun cenderung negative tampil seperti tidak percaya diri, secara fisik terlalu gemuk, tidak mampu memadupadankan cara berpakaian atau kurang mampu menyampaikan pendapat. Konsep-konsep ini ditemukan ketika konseling kelompok dilakukan. Mereka menyadari, bahwa mereka belum sepenuhnya aware pada diri mereka sendiri, bahkan ABF menyatakan bahwa dirinya kurang memperhatikan diri daripada orang lain. Dengan demikian persepsi dari lingkungan masih tampak kuat menjadi dasar dari konseli dalam menetapkan tujuan.

Namun demikian, telah terjadi perubahan pada self-awareness berkaitan dengan aktifitas berbelanjanya, yaitu mereka menyadari bahwa mereka aktivitas berbelanja mereka memiliki masalah, yaitu sangat berlebihan. Dalam proses konseling, pada pertemuan ke- empat masing-masing konseli menyampaikan usaha yang sudah mereka lakukan bahwa mereka sudah menyampaikan kepada pihak-pihak yang signifikan bahwa mereka ingin belanja lebih terarah. Selain itu upaya self-instruction pun mereka coba aplikasikan. Memerintahkan kepada diri secara konsisten untuk tidak belanja berlebihan. ABF menjadikan rincian barang yang akan dibelinya sebagai motivator bagi dirinya (sebagai reward). Hal tersebut tampaknya merupakan upaya dari konseli untuk terhindar dari perbaikan sementara pada mood atau harga diri.

Pada aspek kedua, yaitu Strategi Kognitif, menunjukkan hasil yang bervariasi antara sebelum dan sesudah konseling kelompok. Pertama, dalam kontrol perilaku, yaitu AP dan ABF mengalami kenaikan, sedangkan MM tetap. Kedua, pada kontrol kognitif yaitu AP dan ABF hasilnya tetap, sedangkan MM meningkat. Ketiga, kontrol keputusan, yaitu AP dan MM mengalami peningkatan, sedangkan ABF tetap. Keempat, kontrol informasi yaitu AP dan ABF mengalami peningkatan, sedangkan $M M$ hasilnya tetap. Kontrol retrospektif, yaitu AP dan ABF hasilnya tetap, sementara MM mengalami peningkatan. Keenam, kontrol sekunder yaitu AP dan 
MM hasilnya tetap, sementara ABF mengalami peningkatan.

Bervariasinya hasil perubahan kontrol yang diperoleh setelah konseling kelompok, juga dipengaruhi oleh beberapa faktor. Asumsi pertama yang membuat perubahan control, yaitu menunjukkan dominasi kontrol yang dipersepsi paling efektif bagi ketiga subjek untuk dijadikan strategi agar tujuan yang sudah ditetapkan dapat tercapai. Kedua, perbedaan hasil pun muncul dari keyakinan yang selanjutnya dijadikan kontrol oleh subjek (selfefficacy). Meskipun, masing-masing subjek menunjukkan sama-sama mengalami kenaikan pada tiga kontrol dan yang lainnya hasilnya sama sebelum dan sesudah konseling, namun jika dibandingkan rentang kenaikannya, ABF memiliki skor paling tinggi. Hal tersebut karena dari hasil observasi, ABF yang paling memiliki keyakinan bahwa dengan memanfaatkan kontrol-kontrol tersebut, maka upayanya untuk mengontrol aktivitas berbelanjanya akan lebih terarah.

Pada aspek ketiga, yaitu Monitoring dan Evaluasi, yang dihasilkan oleh ketiga subjek adalah pada aspek inilah semua konseli mengalami penigkatan. Secara konsep teori untuk dapat melakukan monitoring dan evaluasi, harus menyadari permasalahan dengan bertanya pada diri sendiri lalu memberi instruksi. Sebetulnya selama proses konseling berlangsung, ketiga subjek menunjukkan kemampuan dalam mengevaluasi dirinya, hanya saja kecenderungannya selalu yang negatif. Konseli kurang mengapresiasi evaluasi yang sifatnya positif. Ketika kemudian, dalam konseling kelompok ditekankan pada salah satu kontrol bahwa pengalaman yang positif memiliki kontribusi, mereka baru menyadari bahwa sebetulnya pengalaman positif dapat dijadikan reward, misalnya AP yang menyatakan dengan mengendalikan kegiatan berbelanja maka ia bisa liburan ke tempat yang diinginkannya. Konseli juga sudah memperlihatkan kemampuan mengevaluasi perilaku disesuaikan dengan norma sosial, namun karena ketiga konseli memiliki karakter yang sama, yaitu samasama orang yang tergantung akan keberadaan orang lain (dependent), reaksi orang sekitar atau sosial bisa menjadi faktor yang membuat konseli belanjanya akan berlebihan atau tidak. Begitu juga dengan evaluasi terhadap reaksi. Selain itu pengetahuan tentang agama juga belum begitu terinternalisasi pada diri konseli, sehingga informasi mengenai "dilarang hidup berlebihan 
dan boros", belum menjadi kendali yang signifikan.

Konseli pun tampaknya belum secara konsisten menerapkan tujuan yang dibuatnya, hal itu diakui oleh konseli. Mereka masih sangat tergoda oleh pengaruh dari luar, sementara kebutuhan untuk konsisten, menurut Swamn dan Pelham (Fiske \& Taylor, 1991), memiliki peranan dalam proses regulasi diri.

Terdapat sebelas aspek dari faktorfaktor kuratif, menurut Yalom (1977), di mana pada dasarnya kesebelas faktor kuratif ini adalah satu kesatuan yang harus terjadi dalam konseling kelompok. Berikut adalah faktor kuratif yang terjadi pada proses konseling kelompok dalam peningkatan regulasi diri. Pada faktor membina harapan, setiap konseli mengungkapkan harapan mereka pada sesi pertama. Semua konseli memiliki harapan yang sama yaitu berbelanja berlebihannya menjadi hilang. Namun, keyakinan harapan tersebut akan terwujud baru muncul ketika di pertemuan ketiga dan keempat, saat masuk ke tahap kohesivitas dan produktivitas terjadi. Awalnya mereka tidak terlalu yakin, karena orang-orang terdekat tampak banyak yang menyangsikan.

Dalam proses konseling pun dipengaruhi oleh faktor universalitas, yaitu klien tampak menyadari bahwa dirinya tidak sendirian dengan perasaan dan problemnya. Ketika mereka saling menceritakan dan bertukar Informasi mengenai pengalaman mereka dalam melakukan kegiatan berbelanja serta mengendalikan dorongan berbelanjanya. Dalam konseling kelompok ini pun terjadi faktor altruisme, yaitu saling mendukung dan memberikan saran untuk saling membantu anggota lain mengatasi masalahnya. Misalnya ketika MM mengalami masalah dengan tantenya yang sering sirik, ABF dan AP memberi feedback kepada MM bahwa dirinya harus bangga karena menjadi orang yang dijadikan acuan oleh tantenya dari segi fashion. ABF pun mendapatkan feedback dari MM untuk bisa asertif kepada ayahnya, karena MM akhirnya mampu menyampaikan kepada ayahnya untuk tidak selalu memenuhi keinginannya.

Pada saat tahap keempat, terjadi proses pengulangan korektif keluarga primer, yaitu saat konselor memberikan latihan untuk kegiatan berbelanja subjek menjadi lebih bertujuan, memiliki strategi dan adanya monitoring dan evaluasi pada kegiatan belanja yang direncanakan. Pada konseling kelompok ini ternyata diperoleh data bahwa subjek memilki hubungan yang kurang optimal dengan orangtuanya. MM dengan ayahnya yang selalu dipersepsi memberikan 
janji ketika MM memiliki keinginan, $A B F$ yang mempersepsi bahwa ayahnya menyatakan sayang hanya melalui materi dan AP mempersepsi ibunya yang sering mengkritik cara berpakaiannya. Kesamaan persepsi mereka pada orang tua adalah, orang tua yang menunjukkan kebiasaan belanja berlebihan. Ibu AP yang sering belanja jika ayah tidak ada, Ibu ABF yang suka belanja ketika sedang kesal, dan Ibu MM yang juga suka belanja namun MM mengatakan tidak terlalu parah jika dibandingkan dengan dirinya. Sehingga mereka menangkap kesimpulan bahwa pihak-pihak itu harus diinformasikan bahwa subjek-subjek sedang mengikuti konseling kelompok dan ingin kegiatan belanjanya bukan berdasarkan emosi negatif dan bukan yang tanpa tujuan.

MM dan AP berhasil mengemukakan kepada orang tuanya mengenai harapannya mengikuti konseling kelompok dan strategi yang sudah dibuatnya untuk kegiatan berbelanjanya menjadi lebih terarah. Mereka menyampaikan tujuan, strategi (seperti jadwal belanja, daftar belanja, dan lain-lain) serta evaluasi yang akan mereka lakukan, kepada orangtua mereka. Hal tersebut disampaikan setelah pertemuan ketiga, setelah pada pertemuan ini mereka melakukan roleplay untuk content yang akan disampaikan pada orang tua mereka. Tampak setelah hal tersebut dilakukan keyakinan subjek menjadi lebih meningkat. Nampak ABF belum mampu menyelesaikan kesulitan asertif kepada orang tuanya.

Pada konseling kelompok ini pun nampak sudah saling memberikan feedback dan saling meniru perilaku, misalnya ketika AP menyampaikan bahwa dengan menabung maka dirinya akan memberikan reward pada dirinya berupa pergi liburan, maka MM dan $\mathrm{ABF}$ mengatakan bahwa perlu diberikan juga punishment jika mereka berbelanja secara berlebihan lagi. Subjek juga tempak mampu mengekspresikan dirinya kepada anggota lain. Namun, prosesnya bertahap. $A B F$ atau MM secara bergan-tian selalu mulai pertama mengungkapkan pendapat, sementara AP selalu terakhir karena menghormati $\mathrm{AP}$ dan $\mathrm{ABF}$ yang merupakan kakak kelasnya.

Kohesivitas Kelompok terjadi secara optimal pada kelompok ini. Setiap konseli terlihat merasa memiliki dan diterima oleh anggota kelompok, mereka secara terus menerus menjalin kontak dengan anggota kelompok selama proses berlangsung. Konseli tampak selalu saling memberi feedback. Meskipun selalu tampak masih malu ketika harus menceritakan masalahnya. 
Konseli pun dalam menceritakan perasaan yang positif maupun yang negatif kepada anggota lain (katarsis), yang dapat mengekspresikan perasaannya. Konseli menyadari tentang eksistensi hidup, yang perlu tanggung jawab, mereka menyadari bahwa mereka adalah perempuan yang akan menajdi seorang istri, mereka tidak ingin jika kegiatan belanjanya tetap tidak terarah dan tidak berstrategi maka mereka tidak akan menjadi istri yang baik. ABF bahkan menyadari jika saat ini ia masih belum bekerja, ayah yang masih mendukung kebutuhan keuangannya. la tidak ingin jika nanti sudah bekerja, gajinya hanya habis untuk belanja berlebihan yang tidak bermanfaat.

\section{SIMPULAN DAN SARAN}

\section{Simpulan}

Berdasarkan hasil penelitian didapat hasil bahwa terdapat pengaruh pemberian konseling kelompok regulasi diri terhadap peningkatan regulasi diri. Penelitian menguji dan menganalisis data kuantitatif dan kualitatif, maka dapat ditarik kesimpulan sebagai berikut. Pertama: Konseli 1 (AP) dan konseli 3 (MM) mengalami peningkatan peningkatan skor regulasi diri sebelum dan sesudah konseling kelompok, namun kriterianya masih ada di kategori sedang. Konseli 2 (ABF) yang mengalami peningkatan peningkatan skor regulasi diri sebelum dan sesudah konseling kelompok, serta mengalami peningkatan kategori dari kategori sedang bergerak ke kategori tinggi. Selain perubahanperubahan yang terjadi pada variabel regulasi diri, faktor yang juga paling berpengaruh pada proses regulasi diri pada subjek penelitian adalah perhatian subjek yang lebih banyak keluar dari diri. Subjek cenderung menunjukkan perilaku self-focus, yang cenderung bertahan pada emosi negatif yang dirasakan subjek, terutama oleh MM. Faktor lainnya adalah dalam motivasi subjek melakukan perubahan, yaitu belum optimalnya secara konsisten berkomitment pada tujuan yang telah ditentukan di awal. Kedua: Perilaku orang tua secara signifikan berpengaruh pada munculnya gangguan pembelian kompulsif pada ketiga subjek.

\section{Saran}

Hal yang dapat dijadikan pertimbangan sebagai masukan dan tindak lanjut. Pertama: saran untuk penelitian serupa, yaitu (a) Melihat perubahan yang beragam pada subjek penelitian, dimana hasilnya masih ada yang tidak mengalami perubahan pada dua aspek yaitu 
penetapan tujuan dan strategi kognitif, maka sebaiknya proses evaluasi dari perilaku belanja berlebihan dilakukan secara lebih mendalam. Pada penelitian ini, peneliti masih belum secara mendalam melakukan proses evaluasi untuk menggali self-awareness pada subjek. (b) Adanya pengaruh significant person yaitu orang tua yang mefasilitasi subjek untuk perilaku pembelian kompulsif, sehingga perlu dilibatkan juga orang tua dalam proses konseling kelompok. Significant person selain orang tua, sebagai pendukung menurunnya gangguan pun dapat dilibatkan dalam proses konseling kelompok, yang dapat menjadi faktor pendukung peningkatan regulasi diri.

Kedua: saran untuk subjek penelitian, yaitu (a) Untuk subjek 1 (AP) perlu memantapkan kembali penetapan tujuan. Kemudian AP dapat memaksimalkan kontrol yang sudah efektif berfungsi mengontrol perilaku belanjanya. AP juga dapat meningkatkan kontrol lain yang juga berpengaruh. Kontrol yang belum mengalami peningkatan adalah kontrol kognitif, kontrol retrospektif dan kontrol sekunder. (b) Untuk subjek 2 (ABF) dapat memaksimalkan kontrol yang sudah efektif berfungsi mengontrol perilaku belanjanya. Kontrol yang belum mengalami peningkatan adalah kontrol kognitif, kontrol keputusan dan kontrol sekunder. (c) Untuk subjek 3 (MM) perlu melihat kembali secara mendalam evaluasi terhadap penyebab belanja berlebihannya, karena hal tersebut berpengaruh pada kembali penetapan tujuan. MM juga perlu menurunkan emosi yang negatif yang muncul karena ketidaksukaannya pada saudara ibunya. Kemudian MM dapat memaksimalkan kontrol yang sudah efektif berfungsi mengontrol perilaku belanjanya. MM juga dapat meningkatkan kontrol lain yang juga berpengaruh. Kontrol yang belum mengalami peningkatan adalah kontrol perilaku, kontrol informasi, dan kontrol sekunder.

\section{DAFTAR PUSTAKA}

Baumeister, R.F \& Vois, K.D. (2004). Handbook of Self Regulation (Research, Theory and Application). New York: The Guilford Press

Corey, G. (1995). Theory and Practice the Group Counseling (4 $4^{\text {th }}$ Edition). Monterey, CA: Brooks, Cole

Diclemente. C.C. (2003). Addiction and Change. USA: Guilford Press

Fiske, S.T. \& Taylor, E.C. (1991). Social Cognition, Second Edition. Singapore: McGraw-Hill. 
Fitriyani. (2013). Pengaruh Terapi Kognitif dengan Konsep Sabar terhadap Penurunan Coping Strategy Avoidance pada Mahasiswa Ketergantungan Alkohol di Universitas Islam Bandung. Tesis. Bandung: Program Pascasarjana Magister Psikologi Universitas Islam Bandung

Gazda, G.M. (1989). Group Counseling, $4^{\text {th }}$ Edition. Allyn and Bacon (Boston)

Gibson, R.L \& Mitchell, M.H. (1981). Introduction to Counseling and Guidance. Second Edition. New York: Mc Millan Publishing

Jones, R.N. (1982). The Theory and Practice of Counselling Psychology. Holt, Rinehart and Winston.

Hastuti. (1998). Hubungan Antara Religiusitas, Regulasi Diri dan Aktivitas Seksual dalam Berpacaran pada Remaja Kristen. Tesis. Jakarta: Program Pasca Sarjana Universitas Indonesia

Hatta, M.I. (2010). Intervensi Konseling Kelompok Bagi Peningkatan Self Regulation Pada Pemakai Zat Addictive. Tesis. Bandung: Program Pascasarjana Magister Psikologi Universitas Islam Bandung
Latipun. (2010). Psikologi Konseling, Edisi Ketiga. Malang: UPT Penerbitan Universitas Muhammadiyah Malang

Lavallee, L. F \& Capbell, J.D. (1995). Impact of Personal Goals on Self Regulation Processes Elicited by Daily Negative Events. Journal Personality and Social Psychology, 69, 2, 341-352. American Psychology Association Inc.

Müller, A. \& Mitchell, J.E. (2011). Compulsive Buying, Clinical Foundation and Treatment. New York: Routledge

Noor, H. Psikometri- Aplikasi Dalam Penyusunan Instrumen Pengukuran Perilaku. Cetakan Kedua. Bandung: Jauhar Mandiri

O'Connor, K. (2005). Addicted to Shopping and Other Issues Woman Have with Money. Oregon: Harvest House Publisher

Seligman, L. \& Reichenberg, L.W. (2007). Selecting Effective Treatments, Third Edition. USA: John Wiley \& Sons, Inc

Susanto, J. Takeuchi K. \& Nakata, H. (2005). Pengantar Penelitian dengan Subyek Tunggal. University of Tsubuka: Centre for Research on 
International Cooperation in Educational Development (CRICED).

Thombs, D.L. (2006). Introduction to Behaviors, Third Edition. USA: Guilford Incorporated

Thsoleh, S. N. (2011). Pengaruh Konseling Kelompok Terhadap Self Control Pada Santri Putri yang Melanggar Disiplin di Pesantren $X$ Bandung. Tesis. Bandung: Program Pascasarjana Magister Psikologi Universitas Islam Bandung
Watson, D.L. (1989). Self Directed Behavior: Self Modification for Personal Adjusment. California; Cole Publishing Company

Woolfolk, A. E. (1993). Educational Psychology. USA Boston: Allyn \& Bacon

Yalom, I.D. (1985). The Theory and Practice of Group Psychoterapy, Basic Book. A Division of Harpercollins Publisher. 